\title{
LOW NOx BURNER FOR PELLETIZING PLANTS*
}

\author{
Andreas Munko ${ }^{1}$ \\ Fernando Luiz Câmara Campos Junior ${ }^{2}$ \\ Matthias Bergmann ${ }^{3}$ \\ Maycon Athayde 4 \\ Robert Maduta ${ }^{5}$ \\ Tobias Heyd ${ }^{6}$
}

\section{Resumo}

A Outotec está desenvolvendo em escala piloto o queimador de baixa emissão de $\mathrm{NO}_{x}$ desde 2012, resultados expressivos foram atingidos (o pedido de Patente já foi depositado). Em 2014 utilizando simulações CFD, os resultados atingidos em escala piloto foram reproduzidos com boa aderência e os resultados em escala industrial se mostram com os mesmos comportamentos em tendências dos resultados da escala piloto, se mostrando promissores também. O presente trabalho apresenta os passos de desenvolvimento, os promissores resultados e o próximo passo deste desenvolvimento é realizar um teste em escala industrial com o queimador desenvolvido.

Palavras-chave: NOx; Queimadores; Pelotização; CFD.

\section{Abstract}

\section{LOW NOx BURNER FOR PELLETIZING PLANTS}

Outotec is developing in small scale the low $\mathrm{NO}_{x}$ burner since 2012, and the expressive results are reached (the Patent application was requested). In 2014 using CFD simulation, the small scale results were reproduced with very good adherence and the results of industrial scale simulation shoed the same behavior as well, it showing promising too. The present work shows the development steps, the promising results and the next step of this development is to make a industrial test of the burner developed.

Keywords: NOx; Burners;Pelletizing; CFD.

1 Mechanical Engineer, Dr.-Ing., Senior Project Engineer, Mechanical Engineering - Combustion Technology, BU-Metals, Energy \& Water, Outotec, Oberusel, Germany.

2 Metallurgical Engineer, Senior Technical Services Engineer, Technical Services - Agglomeration, BU- Metals, Energy \& Water, Outotec, Belo Horizonte, Brazil.

3 Metallurgical Engineer, Head of Technical Services, Technical Services, BU-Metals, Energy \& Water, Outotec, Oberusel, Germany.

4 Metallurgical Engineer,Msc-Ing.Senior Product Engineer, Technical Services, BU-Metals, Energy \& Water, Outotec, Oberusel, Germany.

5 Mechanical Engineer, Dr.-Ing., Senior R\&D Engineer, BF-Products \& Technologies, BU- Metals, Energy \& Water, Outotec, Oberusel, Germany.

6 Mechanical Engineer, Project Engineer, Mechanical Engineering - Combustion Technology, BUMetals, Energy \& Water, Outotec, Oberusel, Germany. 


\section{SUMARY}

The sustainable use of the natural resources is a subject that definitely incorporated in engineering development at the actual time. The mechanism of clean development it's been since of 1997 and have as the base the Quioto Protocoll, with the scope to promote the sustainable development of the Developing Countries and to support the Developed Countries to reduce their Greenhouse gas emission.

The fact is more and more have an increasingly pressure of the Community per actions associated to the climatic changes.

The actual combustions systems have as a product thermal/mechanical energy, that is sent to the process, and the sub-products where are the Nitrogen Oxide $\left(\mathrm{NO}_{\mathrm{x}}\right.$, Suffer Oxide, the organics volatile compounds, dust, Monocarbon Oxide $(\mathrm{CO})$ and the Nitrogen Dioxide $\left(\mathrm{N}_{2} \mathrm{O}\right)$.

According EPA[1] are considered three kind of Nitrogen Oxide formation mechanisms:

i. $\quad \mathrm{NO}$ formation by Nitrogen chemistry conversion contente in the fuel, called NO fuel.

ii. $\quad \mathrm{NO}$ formation by thermal dissociation of $\mathrm{N}_{2}$ and $\mathrm{O}_{2}$ content in the atmosphere in subsequent combustion reaction. Virtually, every thermal NO is formed in the highest temperature zone, where the combustion air reaches suitable mix level to produce temperature peaks.

iii. NO Prompt formation that occurs by nitrogen molecular reactions (main of the air) with hydrocarbon radicals. This reactions happens in the flame region, close to the light region and normally are contemptible when compared with the amount of NO formed by thermal NO mechanism.

According Ferreira[2] the predominance the one of mechanism mentioned is featured for the conditions that happens the combustion process:

i. High temperatures, thermal NO predominance;

ii. If the amount of nitrogen content in the fuel is high and the temperature is low, the NO fuel and NO prompt are prevailing.

Of describe mechanisms, according Lefebvre et al[3] the thermal NO formation is predominant when natural gas is burned in the combustion system, where happens by the nitrogen content in the atmospheric air with oxygen dissociated by high temperatures resulted of combustion process. This situation the NO formation rate come significant in the temperatures close to $1850 \mathrm{~K}$.

Martins e Ferreira[4] reported that $\mathrm{NO}_{x}$ issued during combustion process is dependent of the fuel composition, operation mode, the burn project and the combustion chamber, where one of each parameters is significant regarding final $\mathrm{NO}_{x}$ concentration. Also according them the control combustion techniques take advantages of kinetic mechanisms of $\mathrm{NO}_{x}$ formation using the flow rate control o fair or fuel or adding inhibitors.

The present paper is more one-step in favor of reduction of Greenhouse gas, particularly, the technical discussion of the development of the burners that results in the considerable reduction of $\mathrm{NO}_{x}$ emission.

All development until this moment occurred in the small scale, witch confirmation of the expressive results of reduction of $\mathrm{NO}_{x}$ emission intends to realize the industrial tests to prove the behavior observed and make the validation of the burner as a Low $\mathrm{NO}$ x Burn for pelletizing plants. 


\section{MATERIALS AND METHODS}

The Outotec Low NOx burner was Project with the 350kW of power with the duplex concept, where have the concentric tubes for primary air and natural gas passage.

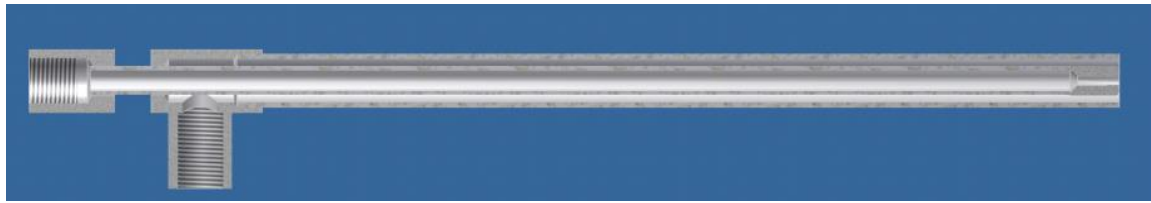

Picture 1. Duplex spears.

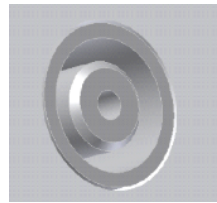

For the tests, a flange was projected to be possible to evaluate up to 6 spears simultaneously as Picture bellow:

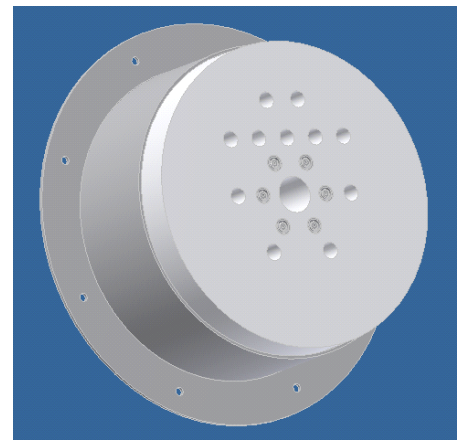

Picture 2. Flange developed for utilization in the combustion chamber.

For the tests realizations, was used during all development the Gas-WaermeInstitute(GWI) furnace in Essen, Germany. The furnace can reach $1300^{\circ} \mathrm{C}$ with a regenerator that worked as a hot air supplier $\left(\mathrm{T} \max =1100^{\circ} \mathrm{C}\right)$, simulating the heated air of down comers.

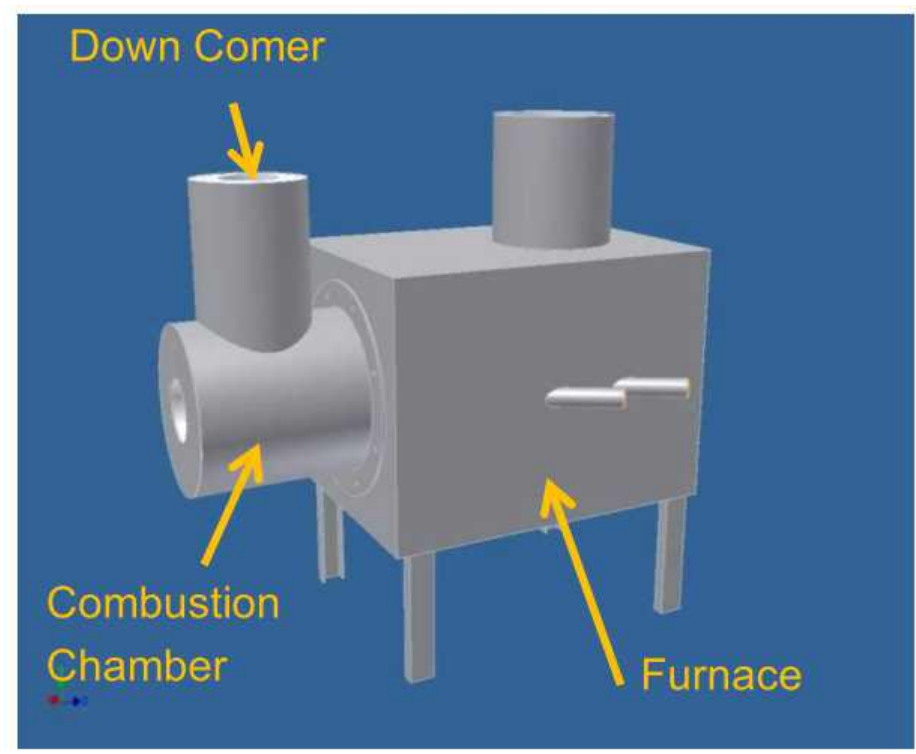

Picture 3. Test configuration scheme used join the furnace of GWI.

To compare the results of the Outotec Low NOx burner, a standard burner, using in the combustion system of gas pelletizing plants with $1000 \mathrm{~kW}$ was available. 
Differents nozzles and spears types were used to cause, mainly the gas andr primary air speed variation.

The small scale tests have been done with the Low NOx burner of $350 \mathrm{~kW}$, after that was generating a $350 \mathrm{~kW}-\mathrm{CFD}$ model, comparison of the CFD model, and them Up scaling of CFD model to $4000 \mathrm{~kW}$ burner.

\section{RESULTS AND DISCUSSION}

Could be verified that the flame resulted of the prototype burner developed by Outotec showed a very good stability, considering the followed parameters:

- Down Comer air temperature: $900 \sim 1050^{\circ} \mathrm{C}$;

- $\mathrm{O}_{2}$ content in the furnace atmosphere:14 16\%;

- Furnace temperature:1050 1150 ${ }^{\circ} \mathrm{C}$;

Picture 4 presents the flame of the Outotec Standard burner prototype during the tests:

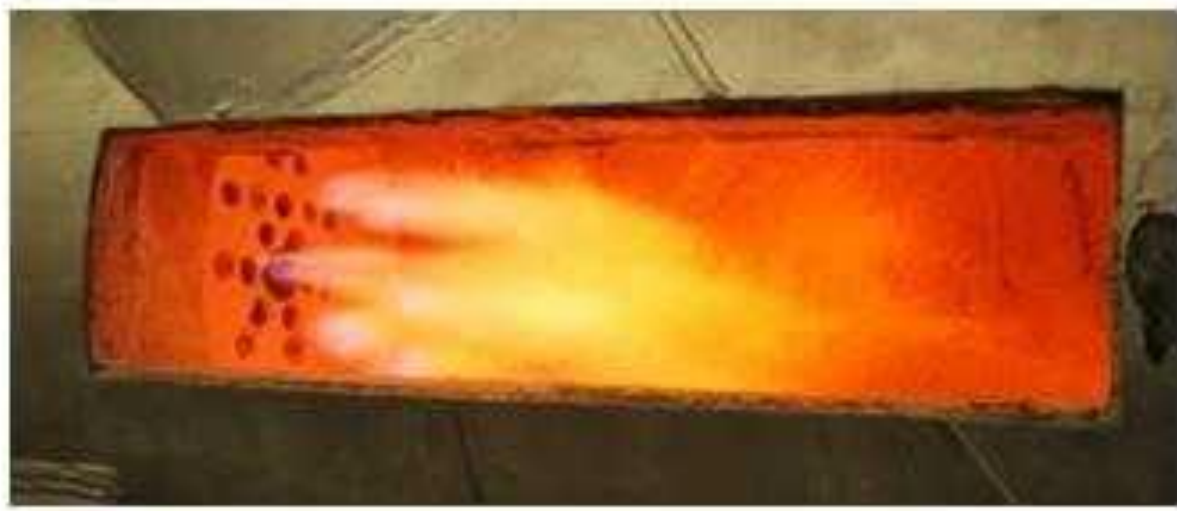

Picture 4. Flame resulted of natural gas burn.

The burner behavior how the emission was presented in the graphic showed a known behavior between gas down comer temperature and $\mathrm{NO}_{\mathrm{x}}$ emission.

Was also verified that the Low $\mathrm{NO}_{\mathrm{x}}$ burner showed very close behavior of the available standard burner.

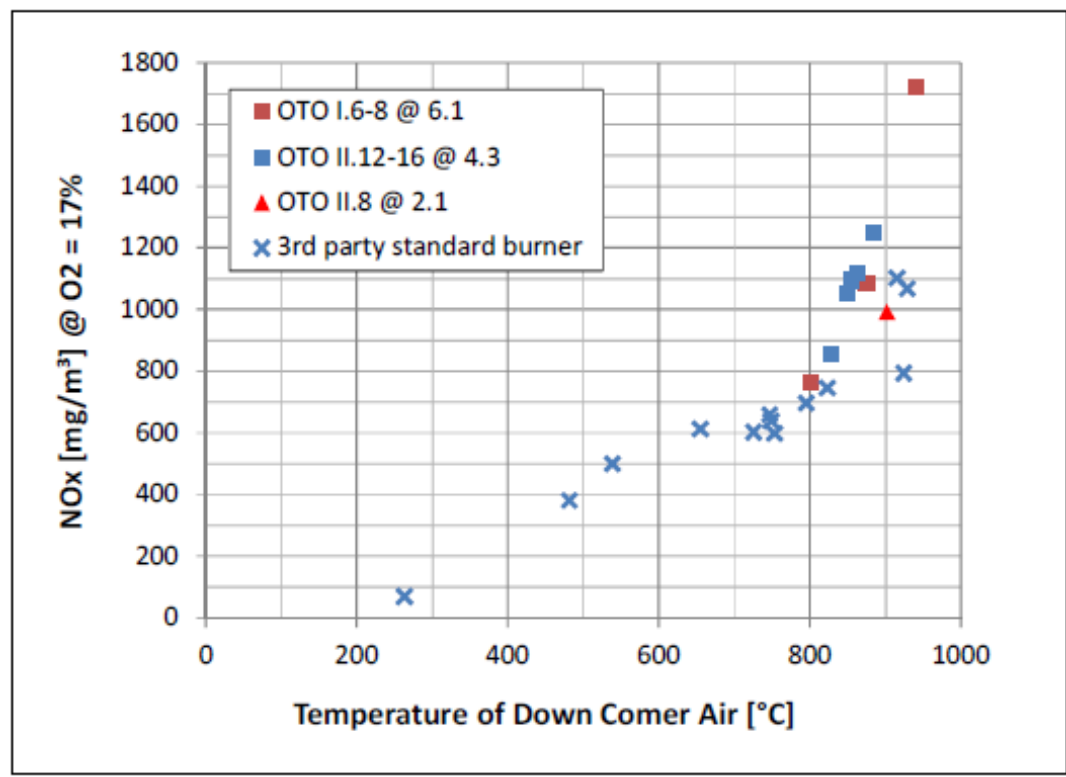

Picture 5. $\mathrm{NO}_{x}$ emission vs Temperature. 
For the development and test of the Low NOx burner, dimensions of nozzles and spears as well as system parameters have been varied.

In this evaluation was possible to verify the bigger influence of nozzle dimension and primary air overage in the $\mathrm{NO}_{x}$ emission.

The picture 6 presents many tests made with nozzles, spears, and varying the flow rate of primary air gas and natural gas, aiming to find the best configuration of lower NOx emission.

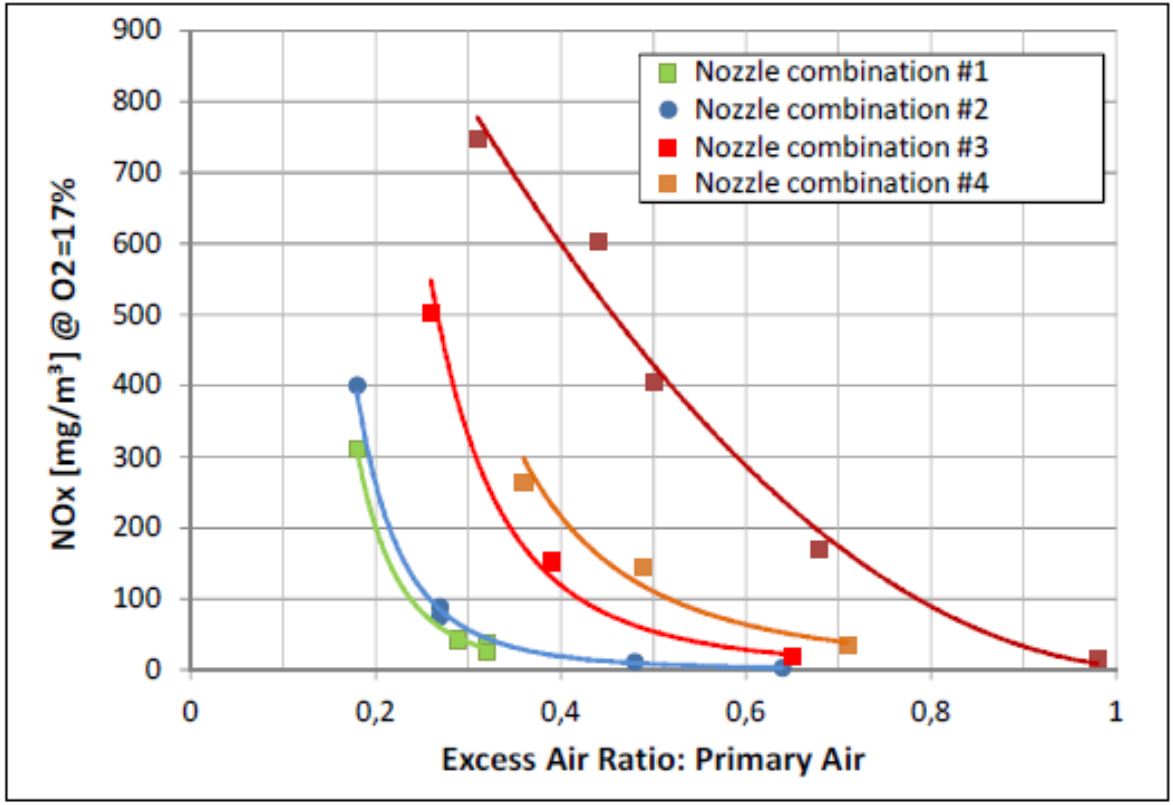

Picture 6. Result of operational condition vs $\mathrm{NO}_{x}$ emission.

It's very clear the positive influence of the air primary overage combination with appropriate nozzle design in the reduction of $\mathrm{NO}_{x}$ emission. The increase of primary air flow rate influence directly the flame shape, give it the aspect of lifted flame.

In the standard flame, the flames color may change of the yellow to orange, resulting in high peaks of temperature and irregular temperature distribution. These flames normally results in high amount of $\mathrm{NO}_{x}$ emission mainly because of high temperature results of this flames. These flames shows very high stability shape.

The lifted flame showed a shape stability different from standard flame, results in lower flame temperature, but a very good temperature distribution. Therefore, by the temperature reduction, it's possible to reach low $\mathrm{NO}_{\mathrm{x}}$ emission, fact that the temperature reduction is mandatory in the $\mathrm{NO}_{x}$ emission reduction.

By flame observation, thus it classified the flames as the $\mathrm{NO}_{\mathrm{x}}$ emission:

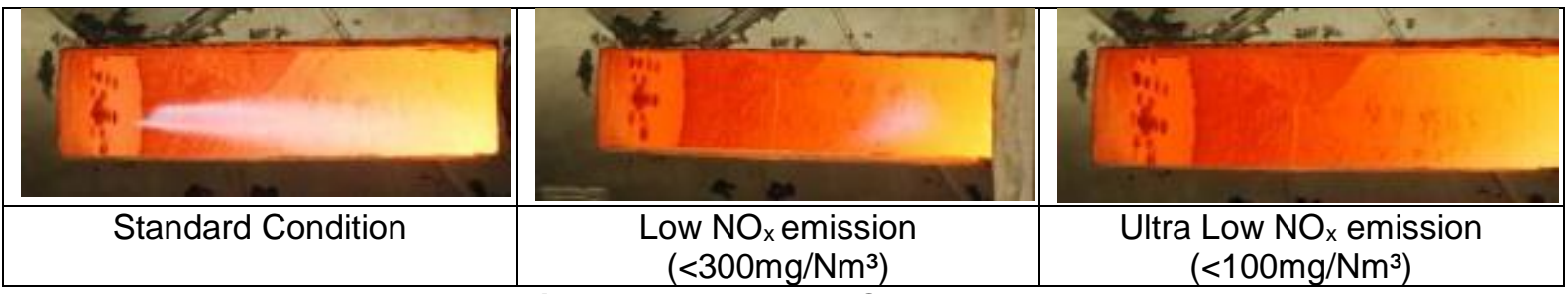

Picture 7. Flames $x \mathrm{NO}_{x}$ emission. 
The operational conditions of the pelletizing plant must be investigated, but according of the concept and visualizations in the small scale, the design shape and flame positioning can result in schematic condition showed bellow:

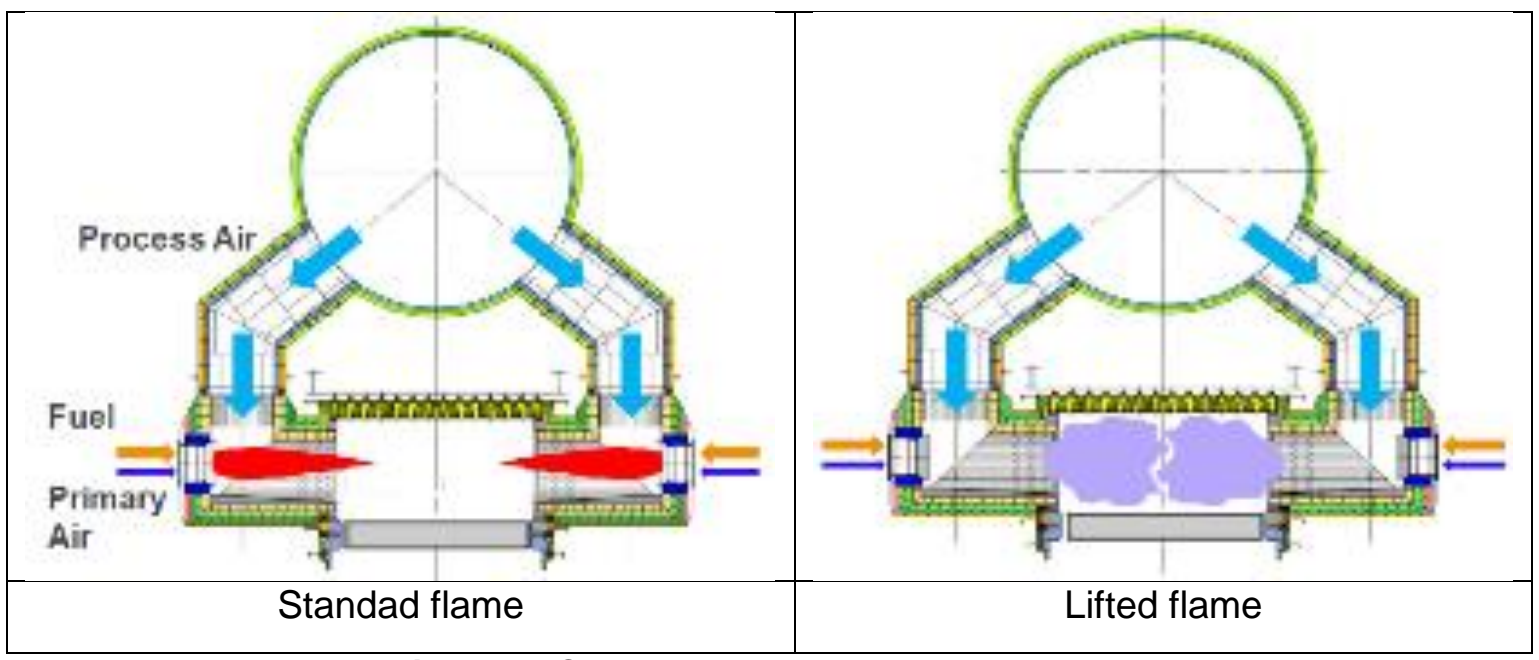

Picture 8. Operation condition - Pelletizing plant.

There are some advantages of the lifted flame condition, it will be cited in this paper for the conceptualization, but all need of more investigation in industrial scale to be validated. The advantages of lifted flame are:

- High uniformity of temperature and flame temperature reduction that results in low NOx emission;

- Low combustion chamber temperature;

- Damages in refractory cam be avoided;

- The lifted flame can be obtained using oil as well;

- Bed temperature e uniformity;

- Increase the fired pellet quality:

The bigger disadvantage between the standard condition is denominate thermal penalty, can be verified that to reach $\mathrm{NO}_{x}$ emission $<100 \mathrm{mg} / \mathrm{Nm}^{3}$, is necessary to work with air primary overage in the range of 0.2 until 0.45 , depending of the down comer temperature gas. In the normal operational condition, the pelletizing plant project developed by Outotec, the normally primary air overage is 0.1 .

Therefore, to work in the low $\mathrm{NO}_{x}$ condition the primary air volume must to be increased. As this volume of the primary air needed to be warmed until $1300^{\circ} \mathrm{C}$, the additional energy volume needed to be consumed, penalizing the process thermally. Outotec has calculated the thermal penalty in an additional process study. This study showed that for Low NOx operation the total OPEX increase is $<9 \%$ and strongly depending on the process air temperature in the down comers.

In fact, is necessary to balance the $\mathrm{NO}_{x}$ reduction and the thermal penalty, thus the thermal penalty can affected significantly the operational cost.

Are showed the behaviors calculated by CFD simulation regarding the flame shape and the $\mathrm{NO}_{x}$ emission. The results measured in the small scale have very close behavior with the CFD simulation. Industrial scale CFD simulation have been done considering the operational data.

Could be verified that according to the results that the flame shape is trending to the lifted flame. 
Some comparative results are presented bellow:

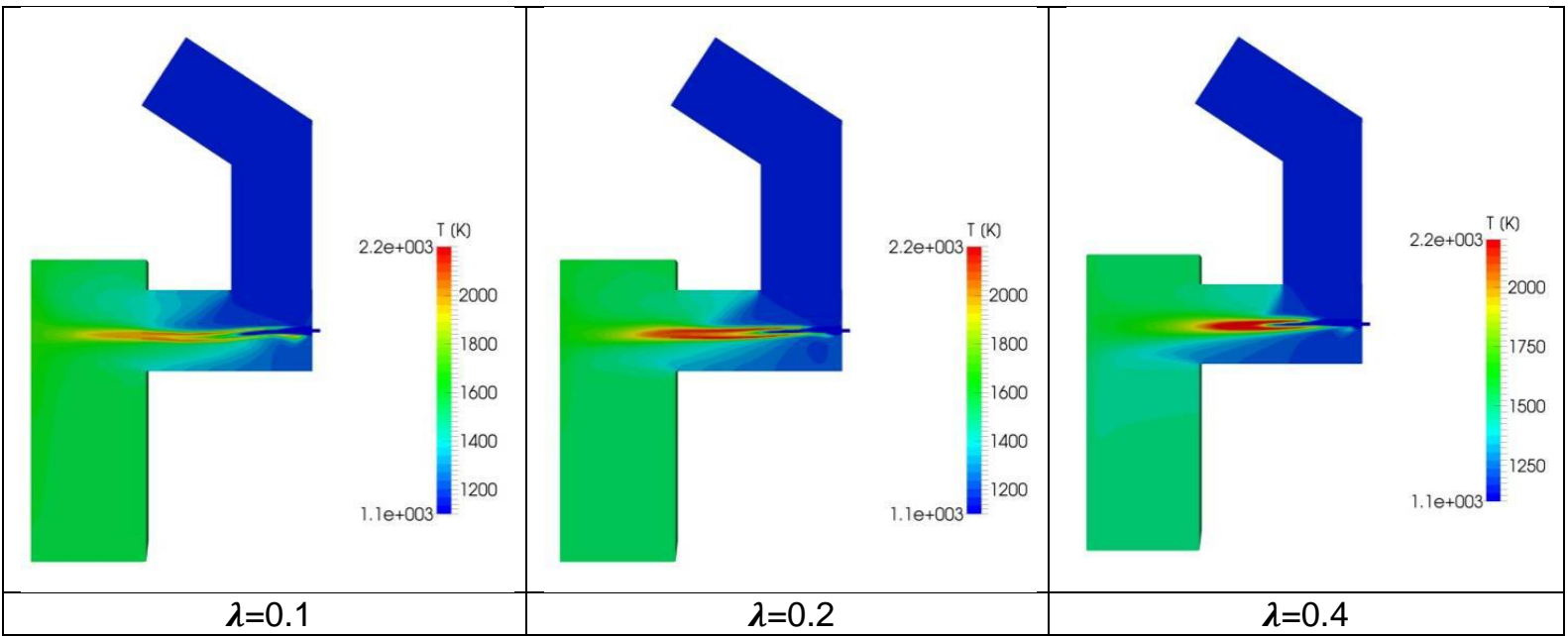

Picture 9. .CFD - Temperature and flame shape.

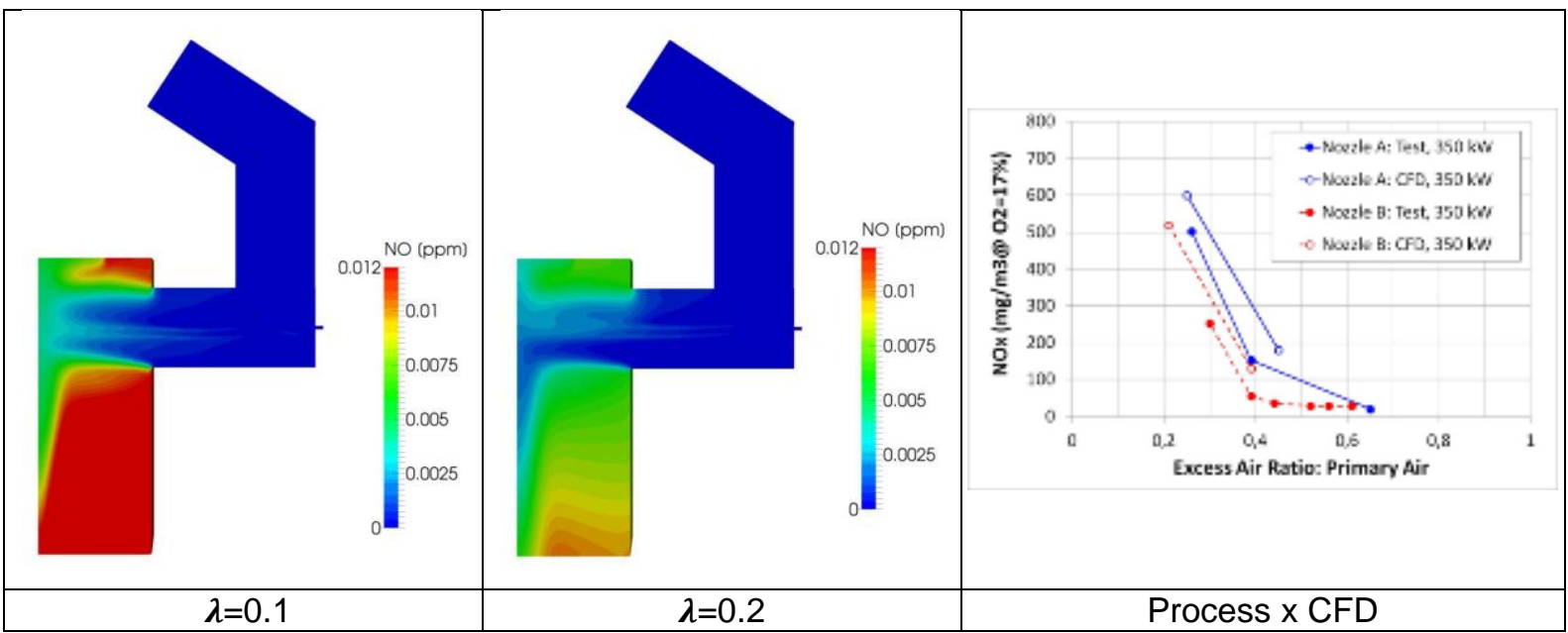

Picture 10. .CFD - NOx emission and comparisons.

For the close results and very high amount of $\mathrm{NO}_{x}$ reduction reaches, is necessary to proceed the industrial tests, considering the balance between good results for $\mathrm{NO}_{x}$ emission reduction and the thermal penalty.

\section{CONCLUSION}

The Low $\mathrm{NO}_{x}$ burner developed using the Outotec know How about $\mathrm{NO}_{x}$ formation showed able to be tested in industrial scale to make some comparisons with others technology used in the Brazilian pelletizing plants and around the word.

The alternatives evaluated as nozzles, spears, flows rate and pressures, that showed the best result was overage of primary air in combination with appropriate nozzle dimensions.

The burner in the industrial scale will be developed for tests considering overage primary air indicated by development, as well as other features that may reduce emissions and reduce CAPEX future projects as well as plant modernization in operation. 


\section{REFERENCES}

1 EPA - U.S Environmental Protection Agency. AP-42 Compilation os Air Pollutant Emission Factors. Volume I: Stationary Point and Area Source. Chapter 1: External Combustion Sources. $5^{\text {th }}$ Edition, USEPA, 1998.

2 Ferreira, MC. Desenvolvimento e caracterização de uma câmara de combustão DLNDry Low $\mathrm{NO}_{x}$ com tecnologia LPP - Lean premixed prevaporized. Dissertação de Mestrado em Ciências Mecânicas. Departamento de Engenharia Mecânica. Universidade Brasília, Brasília - DF, 2007.

3 Lefebvre AH, Ballaal DR.Gas Turbine Combustion: Alternative fuels and emissions $.3^{\text {rd }}$ edition. Boca Raton, USA: Taylor and Francis Group, LCC; 2010.

4 Martins CA, Ferreira MC, Considerações sobre a formação de $\mathrm{NO}_{x}$ na Combustão. VI Congresso Nacional de Engenharia Mecânica. Campina Grande - Paraíba, Brasil, 2010. 